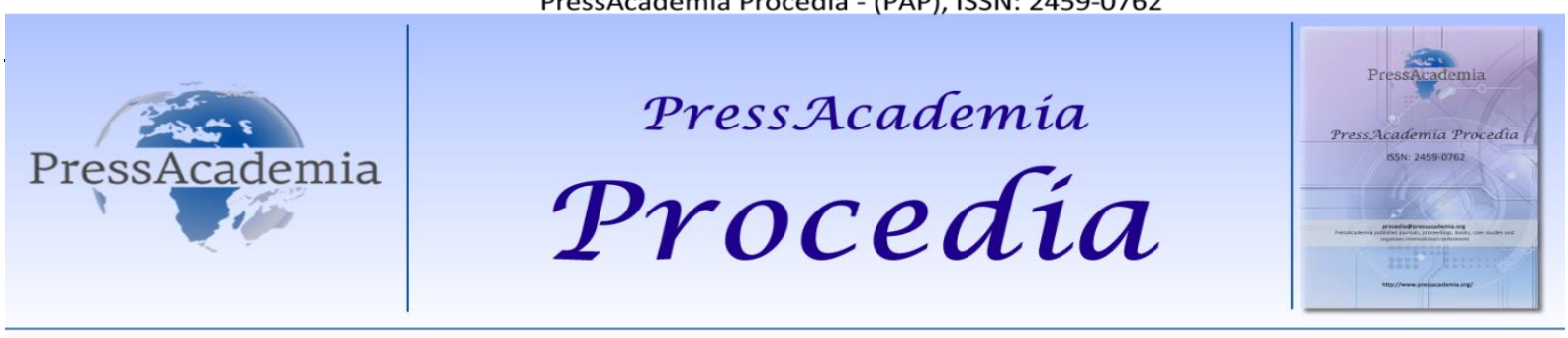

Global Business Research Congress (GBRC), May 24-25, 2017, Istanbul, Turkey.

\title{
THE ROLE AND IMPORTANCE OF E-INFORMATION IN STRUGGLE WITH INFORMALITY: AN EVALUATION IN TERMS OF ACCOUNTING PRACTICES IN TURKEY
}

DOI: 10.17261/Pressacademia.2017.408

PAP-GBRC-V.3-2017(23)-p.229-240

Abdulkerim Dastan ${ }^{1}$, Yasar Bayraktar ${ }^{2}$

${ }^{1}$ Karadeniz Technical University, Faculty of Economics and Administrative Sciences, Trabzon, TURKEY. akdastan25@yahoo.com

${ }^{2}$ Karadeniz Technical University, Faculty of Economics and Administrative Sciences, Trabzon, TURKEY. ysr bayraktar@hotmail.com

To cite this document

Dastan, A. and Y. Bayraktar, (2017), The role and importance of e-information in struggle with informality: an evaluation in terms of accounting practices in Turkey. PressAcademia Procedia (PAP), V.3, p.229-240.

Permemant link to this document: http://doi.org/10.17261/Pressacademia.2017.408

Copyright: Published by PressAcademia and limited licenced re-use rights only.

\begin{abstract}
The purpose of study is to evaluate the role and importance of e-information usage in struggle with informality in terms of accounting practices in Turkey. Revenue Administration has been working on efficient usage of e-information to collect taxes full and timely by using modern methods. In this context, e-declaration, e-invoice, e-ledger and e-notification are put into effect. So the annual reports and changes over the years were examined contextually and evaluated in terms of preventing informality. E-information applications which directly affect accounting profession and its practices by saving time, reducing transaction costs and bringing important results in processes; provide efficiency in auditing and inspection with remote access, fast mobility in operations, decrease in collection costs and increase in collection/accrual rate. E-information applications are important in struggle with informality even if not at the desired level.
\end{abstract}

Keywords: Informality, e-declaration, e-invoice, e-ledger, e-notification

JEL Codes: 017, M41, M48

\section{INTRODUCTION}

The usage of information technology is important both in terms of businesses and public administrations in order to be able to adapt to developments and changes brought about by the information age. As a matter of fact, in recent years the developments experienced in economic, social and technological areas, response to the increasing needs of the applications in the quality of the electronic environment, has been come into existence. Accordingly, businesses and public administrations have turned their attention to electronic applications in order to increase their productivity and to use resources more effectively. These applications provide parties unlimited mobility, independently of both time and place at the points of accessibility, operation and control. On the other hand, increasing number of electronic transactions in every field of activity has inevitably necessitated the integration of taxation activities into electronic system in terms of both the Revenue Administration (GiB) as a public authority and businesses as a taxpayer. This, of course, has contributed to the processing speed and resource savings.

Tax, which is an important source of funding in public services, refers to share of revenue administration over the tax base determined in financial information production process by the accounting information system in terms of taxable income. 
The efficient and continuous collection of these taxes is directly related to service that will be provided to the public. However, situations such as state does not use the tax collected from the private sector on productive and rational expenditures, excess of exemptions, reductions and exceptions in taxation systems, deficiency of tax auditing coordination and lack of tax penalties deterrence, increase resistance to pay tax while weakening taxpayer's tax consciousness. Thus, while tax loss and evasion's share increase in economy, income distribution deteriorates and social justice becomes difficult to achieve. GiB whose mission is to protect taxpayer rights and to ensure voluntary compliance with tax, is conducting studies on electronic applications to collect taxes and other incomes from taxpayers fully, timely and regularly and to increase efficiency in tax auditing. In this context, electronic applications such as e-declaration, e-invoice, e-ledger, enotification, e-declaration, e-poll and e-payroll have been put into effect in recent years. Through these applications, it is aimed to reduce the share of informality in the national economy.

The purpose of this study, which is discussed in light of the above explanations, is to evaluate the role and importance of einformation usage in struggle with informality in terms of accounting practices in Turkey. However, it is difficult to evaluate statistically and econometrically as a constraint that the data in the examined reports in this study were published annually. For this reason, the operating reports have been examined contextually, and in the study, evaluations have been made with particular emphasis on electronic applications, in general, tax loss and evasion and informality. In this context, theoretically, the concepts of e-declaration, e-invoice, e-ledger and e-notification are mentioned at the point of informality and electronic applications and after the literature review, the usage of e-information in Turkey is evaluated whether is effective in preventing informality or not.

\section{GENERAL CONCEPTS}

Informality which is called underground economy, shadow economy, informal economy, black economy, unofficial economy, hidden economy, parallel economy, is expressed as revenue-generating economic activities in legal and illegal areas in which is out of knowledge and control of Revenue Administration with official gross national product (Schneider, 2005: 2; Schneider and Williams, 2013: 23).

Due to the quantity and quality of informality varies according to development level of countries, socio-economic structure of society and moral levels of individuals. On the other hand, ineffective and weak state structure, inflation and economic crises, fiscal burdens on the private sector, the complexity of taxation, the unfairness of tax system, the high rates of taxation, the diversity of tax rates and the constant changes in rates, excess of exemptions, reductions and exceptions in taxation systems, deficiency of tax auditing coordination and lack of tax penalties deterrence, informal employment and the inadequacy of financial consultancy services can be cited as reasons for informality (Rakıcı, 2011: 355; Daştan, 2011: 187). Legal and illegal activities related to informality resulting from monetary and non-monetary transactions are shown in Table1.

Table 1: The Informal Economic Activities

\begin{tabular}{|l|l|l|l|l|}
\hline Type of Activity & \multicolumn{2}{|c|}{ Monetary Transactions } & \multicolumn{2}{c|}{ Non-Monetary Transactions } \\
\hline \multirow{3}{*}{ Illegal Activities } & \multicolumn{1}{|c|}{$\begin{array}{l}\text { Trade with stolen goods; drug dealing and } \\
\text { manufacturing; prostitution; gambling; smuggling; } \\
\text { fraud; etc. }\end{array}$} & $\begin{array}{l}\text { Tax Avoidance } \\
\text { Barter of drugs, stolen goods, smugling etc. Producing } \\
\text { or growing drugs for own use. Theft for own use. }\end{array}$ & \multicolumn{1}{c|}{ Tax Evasion } & \multicolumn{1}{c|}{ Tax Avoidance } \\
\hline \multirow{2}{*}{ Legal Activities } & $\begin{array}{l}\text { Tnreported income } \\
\text { from selfemployment; } \\
\text { Wages, salaries and } \\
\text { assets from unreported } \\
\text { work related to legal. }\end{array}$ & $\begin{array}{l}\text { Employee discounts, } \\
\text { fringe benefits. }\end{array}$ & $\begin{array}{l}\text { Barter of legal services and } \\
\text { goods. }\end{array}$ & $\begin{array}{l}\text { All do-it-yourself work } \\
\text { and neighbour help. }\end{array}$ \\
\hline
\end{tabular}

Resource: Schneider and Buehn, 2016: 2

While informality contributes to economic growth, stability and preventing unemployment in terms of creating employment for unqualified work force; conversely, it mainly causes the loss of functionality of public finance, distortions of competition, waste of resources, inequality in income distribution, reduced income at the tax scale and insecurity against economic indicators (Ay, 2006: 62-64; Bağırzade, 2015: 41-48).

There is a need for registered economy and its sustainability in order to increase the availability of socio-economic equilibrium, to eliminate inequality in income distribution, to achieve sustainable economic growth, to improve the indirect and direct tax distribution and to increase the individuals' confidence in principle of equitable taxation, to provide public services more effectively on the basis of cost-benefit analysis, to increase employment opportunities, to fully utilize the social rights of the workers and to create better working conditions, to increase the competitive power of businesses, to decrease the credit costs, to monitor the consumer rights. In this direct, tax loss which is both cause and consequence of the informal economy should be avoided. 
Tax, one of the state's major sources of income, is not an obligation that is voluntarily committed by citizens because they are taken forcibly (Türker, 2004: 3). Therefore taxpayers avoid taxes by not presenting in tax declaration or pay taxes by using the legal gaps in their interest. In practice, the tax avoidance action, which is performed by using the flexibility arising from the tax legislation, is also known as tax covering and there is no penal sanction. On the other hand, the tax evasion action, which is basically aimed at countervailing the taxation, is realized with some transactions on accounting documents and records which consitutes the basis of determining the tax base of taxpayers. These transactions include errors and fraud which is made to reduce the tax base by distorting accounting records or fraudulent documentation due to their content.

There are a number of reasons why taxpayers are driving the realization of the activities that would lead to tax loss. In this context, the desire to increase net post-tax profits for some taxpayers may be related to economic reasons, some for the perception of tax justice (injustice) related to psychological reasons, and for some, inappropriate expenditure of collected taxes by public authorities related to sociological reasons (Savaşan and Odabaş, 2005: 3). For these reasons, the economic activities contributing to registered economy are excluded from the tax scope. As a result of this situation, while the share of informality in the country's economy increases, income distribution is deteriorated and social justice becomes difficult to achieve. GiB which is in effort to solve these and similar problems, carries out studies about the effective usage of einformation to collect taxes and other incomes from taxpayers fully and timely. Thus, it is aimed to reduce the share of informality in the national economy.

It can be stated that the e-government applications by GiB are started in the framework of Automation Projects of Tax Offices (VEDOP I-II-III) and embodied in the area of Internet Based Tax Office Automation (e-VDO). In this context, electronic applications such as e-declaration, e-invoice, e-ledger, e-notification, e-poll and e-payroll have been put into effect in order to provide tax income layout and taxpayer follow-up. These applications generally enable to prevent informality resulting from tax loss and evasion, particularly, to save money from expenditures, to increase transparency and quality in services, to provide $24 / 7$ service, to make transactions easier with fast and easy access. Descriptive information related to such electronic applications can be summarized as follows.

E-declaration means that the tax declaration indicating the amount of the tax debt is to be submitted to the tax administration in electronic form (Öz and Bozdoğan, 2012: 82).

E-declaration application started in October 2004 to fulfill the taxpayers' taxation duties, to benefit from developing information technologies, to ensure that tax declarations, notifications and attachments are delivered to the tax office in an easy, fast, economical and reliable manner, to reduce taxpayers' mistakes in filling of the tax declarations, to prevent the taxpayer victimization, to facilitate the tax office acceptance, assessment, accrual and collection procedures and to provide better service for taxpayer in other areas (Merter, 2016: 54). As of 2004, 24 million paper and 300000 electronic declarations have been prepared and by the end of 2016, 478000 sheets of paper and approximately 90 million electronic declarations were received electronically. While the e-declaration rate in 2004 was $5 \%$, it was $99,7 \%$ at the end of 2016 (GIB, 2017a: 102). Along with this application, saving speed, time and space in archiving, statistical information extraction and auditing processes are provided and environmental negative externalities are avoided by preventing paper waste.

E-invoice is an electronic document that has been standardized specifically, sealed in an unchangeable format, providing safe, time and cost savings between seller and buyer and including the information required to be in a bill pursuant to the Tax Procedural Code (Azak and Bizimyer, 2016: 154).

The e-invoice application, which has the same legal qualification as paper invoice, was put into effect in March 2010. With the Electronic Invoice Registration System (EIRS), the requirement that some of the information on the invoices be transferred to the GiB system and that the second copies belonging to the invoices should be stored as a paper has been removed. On the other hand, the first copy prepared to be given to buyer has also been created in electronic form and transmitted to buyer (Gökçen and Özdemir, 2016: 143). Thus an important step was taken in preventing tax loss and evasion by ensuring efficiency in tax auditing. On the other hand, the e-archive application related to the e-invoice is put into effect and the costs of printing, storing, archiving and forwarding invoices are reduced.

E-ledger is the whole set of legal and technical regulations that the ledgers which are required to be kept under the Tax Procedural Law and the Turkish Commercial Code, is prepared in electronic file format in accordance with the specified format and standards, to be recorded without repression, to guarantee the integrity of its immutability and its authenticity and enabling them to be used as evidence for relevant parties (Acar and Öksüz, 2013: 76).

In order to prepare this application electronically is based on Extensible Business Reporting Language (XBRL) which is an internationalized standard in XML format. This application contributes to reduction of compliance, archiving and notarization costs arising from bookkeeping in the paper environment, the simultaneous tracking and control of the ledgers and records kept by the businesses, and the improvement of the efficiency in the inspection and auditing. On the other 
hand, in revealing possible manipulations of financial information, the taxpayer will be pressured. Thus, taking advantage of low inspection rate, the taxpayers who think that they will not be included in the inspection, will also contribute to preventing the unrecorded economic activities.

E-notification which is an important part of public administrative proceedings, is made electronically within the framework of the Tax Procedural Code (Arslan and Biniş, 2016: 306).

The notification which is an important topic of the tax law, enables starting of the accrual phase and serve as a bridge between tax levy and tax accruals. As a matter of fact, the beginning of the time interval for the tax debts to become payable and the calculation of certain periods depends on the notification. The document to be submitted to taxpayer is realized by mail, in electronic form, through civil servant, in office or commission, and by announcement (Arslan and Biniş, 2016: 302-304). GiB began implementing e-notifications in April 2016 to save time and resources, to increase transparency in communications, and to minimize potential problems. Thanks to this application, an important distance can be taken to reduce workforce cost and stationary expenses. On the other hand, along with the feedback mechanism, you may also have knowledge of whether the notification reaches the other parties or not.

\section{CURRENT SITUATION OF TAX LOSS-EVASION AND INFORMALITY IN TURKEY}

The data about the effects of tax inspection and tax loss on economic indicators in Turkey are presented to public through annual operating reports as a result of the examinations made by GiB and Turkish Tax Inspection Board (TTIB). In this framework, the ratio of informality to Gross Domestic Product (GDP) in Turkey over the years is shown in Table 2.

Table 2: The Ratio of Informality to GDP

\begin{tabular}{|l|c|c|c|c|c|}
\hline Indicators & $\mathbf{2 0 1 4}$ & $\mathbf{2 0 1 5}$ & $\mathbf{2 0 1 6}$ & $\mathbf{2 0 1 7}$ & $\mathbf{2 0 1 8}$ \\
\hline Ratio of Informality to GDP (\%) & 26,5 & 25 & 24 & 23 & 21,5 \\
\hline Ratio of Unregistered Employee (\%) & 22 & 20 & 19 & 18 & 17 \\
\hline
\end{tabular}

* Non-agricultural sectors have been obtained through non-agricultural employment ratios of informal workers.

Resource: GiB, 2015b: 2

As seen in the table, the share of unregistered employment and in relation to the share of the unregistered economy declines over the years. In this context, as a result of performance by the public administration, it can be stated that the registered working and employment rate is increasing. As a matter of fact, with the projection made for 2018, it is aimed to further reduce the informality rate. In contrast, tax loss and evasion cause the decrease of the registered economy. According to the Turkish tax system, tax based on declarations constitutes approximately $87 \%$ of the general budget revenues by 2016 (GIB, 2017a: 179). In this context, the ratio of general budget tax revenues in GDP and the collection ratios are shown in Table 3.

Table 3: The Ratio of General Budget Tax Revenues in GDP and Collections (Thousand TRY)

\begin{tabular}{|c|c|c|c|c|c|}
\hline Years & GDP & Tax Accruals & Tax Collection & Tax Ratio (\%) & Collection/Accrual (\%) \\
\hline 2011 & 1.394.477.166,- & $332.491 .753,-$ & 284.490.017,- & 20,4 & 85,6 \\
\hline 2012 & 1.569.672.115,- & 366.963.795,- & 317.218.619,- & 20,2 & 86,4 \\
\hline 2013 & 1.809.713.087,- & $423.438 .661,-$ & 367.517.727,-- & 20,3 & 86,8 \\
\hline 2014 & 2.044.465.876,- & 471.415.754,- & 401.683.956,-- & 19,6 & 85,2 \\
\hline 2015 & 2.337.529.940,- & 549.259.835,- & 465.229.389,- & 19,9 & 84,7 \\
\hline 2016 & - & $651.822 .042,-$ & 529.263.765,- & - & 81,2 \\
\hline
\end{tabular}

Resource: http://www.gib.gov.tr/sites/default/files/fileadmin/user_upload/VI/GBG/Tablo_2_18_55_56.xls.htm Access Date: 27.03.2017

As seen in the table, GDP and tax revenues have increased in a direct proportion over the years. As of 2015, the share of tax revenues in GDP is $20 \%$ and the collection/accrual rate is $85 \%$ on average.

On the other hand, a significant portion of tax revenues consists of income, corporate and value added tax. As a matter of fact, income, corporate and value-added tax revenues have a share of 64,1\% in general budget tax revenues as of 2016 (GiB, 2017a: 181). In addition, it can be stated that the collections in terms of tax types and their share in budget tax revenues have increased in recent years. The number of active taxpayers is 5330936 as of 2016 in terms of the type of obligation for taxes collected from taxpayers with an understanding based on declaration principle. However, this number constitutes $17,20 \%$ of the potential number of taxpayers (GiB, 2017a: 165).

In transition to registered economy, it is important to have tax consciousness and tax duty ethics for taxpayers instead of having large numbers of taxpayers. Because, at times, the trust of the state's taxpayer, which is the basis of the declaration principle, can be exploited in consideration of personal or institutional interests. Therefore, the declaration poses a risk in 
terms of tax evasion. As a matter of fact, the main reasons such as taxpayers' lack of tax consciousness, insensitivity to taxation and inadequacy of tax auditing also have a direct impact on the increase of tax loss. In terms of tax loss, the differences between general budget tax accruals and collections are likely to indicate this situation. In this context, it can not be said that there is effectiveness in the collection of the accrued tax revenues over the years. On average, there is a tax collection deficit of $15 \%$. As a matter of fact, a difference of $18,8 \%$ as of 2016 shows that the collection could not be made properly. This difference will lead to tax loss and tax loss will point to the existence of the informal economy.

On the other hand, to what extent the taxpayer's declaration submitted to the Revenue Administration reflects the reality poses a separate problem. This situation raises the issue of tax auditing and its efficiency. As a matter of fact, the tax assessments made based on the taxpayers' previous notifications can not be instantly identified because the tax losses can not be controlled in the current period, thus it causes insufficiency of auditing. Because subsequent inspections make it difficult to appear for deficiencies and errors on books and documents (Daştan, 2011: 186). The quantitative data on tax loss and evasion in Turkey are presented as results of examinations made by GiB and TTIB. In this context, the data related to the examinations made between 2012-2016 are shown in Table 4.

It can be said that the examinations and presented reports according to the tax types are quite low when compared to the active taxpayer numbers. On the other hand, there are fluctuations in the declared tax bases in terms of tax types over the years. However, it can be said that there is a tendency to increase the amount of tax base reported by the effects of economic change parameters and GiB voluntary compliance studies.

Theoretically, the total of the found tax base with the declared tax base gives the total amount of tax that must be collected. In this context, in terms of taxpayers surveyed in the last 5 years, taxpayers who have not been declared in terms of income, corporation and value added tax, which constitute $64,1 \%$ of tax income, average $36,15 \%-35,34 \%$ and $16,83 \%$ respectively. On the other hand, the declared tax base rate of tax base related to taxation is $63,03 \%-58,93 \%-21,22 \%$ respectively. In addition, the number of inspected taxpayers in terms of tax types by 2016 is 6861 . The ratio of the number of inspected taxpayers to the number of potential taxpayers is approximately 1,3\%. Although this ratio is quite small, the rate of non-declared is high. However, in recent years, it can be said that the rates of non-declared have decreased by tax types thanks to the regulations on the prevention of tax loss and evasion. As a matter of fact, it can be said that the usage of e-information is more effective in the framework of e-government applications which are implemented by GiB. 
Table 4: Tax Inspections Between the Years of 2012-2016 (Thousand TRY)

\begin{tabular}{|c|c|c|c|c|c|c|c|c|c|c|c|c|c|c|c|}
\hline Years & 2012 & 2013 & 2014 & 2015 & 2016 & 2012 & 2013 & 2014 & 2015 & 2016 & 2012 & 2013 & 2014 & 2015 & 2016 \\
\hline & \multicolumn{5}{|c|}{ Income Tax } & \multicolumn{5}{|c|}{ Corporation Tax } & \multicolumn{5}{|c|}{ Value Added Tax } \\
\hline Inspected Taxpayers & 1.578 & 1.425 & 1,518 & 1.779 & 911 & 419 & 224 & 214 & 491 & 415 & 4.274 & 2.264 & 1.312 & 2.104 & 1.216 \\
\hline Reports & 2.293 & 1.973 & 2.164 & 2.745 & 1.213 & 475 & 272 & 280 & 642 & 442 & 4.947 & 2.939 & 2.638 & 3.202 & 1.528 \\
\hline Declared Tax & $96.144,-$ & $19.524,-$ & $34.743,--$ & $52.051,-$ & $211.485,-$ & $15.695,-$ & $9.888,-$ & $39.223,-$ & $38.046,-$ & $124.741,-$ & $3.746 .260,-$ & $800.704,-$ & $2.246 .874,--$ & $1.229 .173,-$ & $597.367,-$ \\
\hline Tax Base Difference & $25.582,-$ & $18.476,-$ & $26.827,-$ & $48.157,-$ & $51.161,-$ & $10.625,-$ & $9.435,-$ & $12.231,-$ & $27.709,-$ & $34.354,-$ & $274.357,-$ & $221.229,-$ & $255.123,-$ & $464.869,--$ & $131.314,-$ \\
\hline Difference/Inspected & $26,61 \%$ & $94,63 \%$ & $77,22 \%$ & $92,52 \%$ & $24,19 \%$ & $67,70 \%$ & $95,42 \%$ & $31,18 \%$ & $72,83 \%$ & $27,54 \%$ & $7,32 \%$ & $27,63 \%$ & $11,35 \%$ & $37,82 \%$ & $21,98 \%$ \\
\hline Non-declared & $21,02 \%$ & $48,62 \%$ & $43,57 \%$ & $48,06 \%$ & $19,48 \%$ & $40,37 \%$ & $48,83 \%$ & $23,77 \%$ & $42,14 \%$ & $21,59 \%$ & $6,82 \%$ & $21,65 \%$ & $10,20 \%$ & $27,44 \%$ & $18,02 \%$ \\
\hline Tax Difference & $6.041,-$ & $4.366,-$ & $6.059,-$ & $11.232,-$ & $7.710,-$ & $2.131,-$ & $17.080,-$ & $1.848,-$ & $5.190,-$ & $7.713,-$ & $52.726,-$ & $30.489,-$ & $20.334,-$ & $41.539,-$ & $32.448,-$ \\
\hline Taxable Tax & $7.723,-$ & $5.423,-$ & $5.695,-$ & $13.153,-$ & $9.881,-$ & $2.562,-$ & $2.183,-$ & $2.188,-$ & $5.529,-$ & $7.991,-$ & $71.161,-$ & $41.082,-$ & $19.689,-$ & $57.313,-$ & $33.035,-$ \\
\hline Irregularity Fine & $253,-$ & $74,-$ & $28,-$ & $169,-$ & $14,-$ & $10,-$ & $3,-$ & $359,-$ & $45,-$ & $16,-$ & $389,-$ & $239,-$ & $134,-$ & $56,-$ & $25,-$ \\
\hline Special Irregularity Fine & $23.354,-$ & $22.637,-$ & $22.965,-$ & $39.223,-$ & $5.873,-$ & $3.707,-$ & $2.250,-$ & $2.828,-$ & $6.090,-$ & $2.207,-$ & $24.588,-$ & $259.542,-$ & $13.292,-$ & $13.845,-$ & $5.646,-$ \\
\hline \multirow[t]{2}{*}{ Tax Loss Fine } & $249,-$ & $7.056,-$ & $7.045,-$ & $15.556,-$ & $14.022,-$ & $4.538,-$ & $78.873,-$ & $2.967,-$ & $6.458,-$ & $13.248,-$ & $225.854,-$ & $76.759,-$ & $30.734,-$ & $116.279,-$ & $57.350,-$ \\
\hline & \multicolumn{5}{|c|}{ Private Consumption Tax } & \multicolumn{5}{|c|}{ Bank and Insurance Transaction Tax } & \multicolumn{5}{|c|}{ Inheritance and Transfer Tax } \\
\hline Inspected Taxpayers & 120 & 53 & 55 & 38 & 62 & 13 & \begin{tabular}{r|}
14 \\
\end{tabular} & 16 & 13 & 3 & 2 & 2 & & - & 34 \\
\hline Reports & 135 & 49 & 71 & 44 & 65 & 27 & 22 & 22 & 21 & 5 & 2 & 2 & - & - & 36 \\
\hline Declared Tax & $30.386,-$ & $795,-$ & $15.394,-$ & $3.352 .507,-$ & & $1.071,-$ & - & $44,-$ & $851,-$ & & $1.469,-$ & $5,-$ & - & - & $731.221,-$ \\
\hline Tax Base Difference & $4.411,-$ & $8.339,-$ & $1.841,-$ & $754.010,-$ & $629,-$ & $994,-$ & $668,-$ & $92,-$ & $529,-$ & $144,-$ & - & $347,-$ & & - & $892.437,-$ \\
\hline Difference/Inspected & $14,52 \%$ & $1048,93 \%$ & $11,96 \%$ & $22,49 \%$ & - & $92,81 \%$ & - & $209,09 \%$ & $62,16 \%$ & - & - & $6940,00 \%$ & - & - & $122,05 \%$ \\
\hline Non-declared & $12,68 \%$ & $91,30 \%$ & $10,68 \%$ & $18,36 \%$ & - & $48,14 \%$ & - & $67,65 \%$ & $38,33 \%$ & - & - & $98,58 \%$ & - & - & $54,96 \%$ \\
\hline Tax Difference & $4.620,-$ & $10.639,-$ & $9.191,-$ & $290.398,-$ & $677,-$ & $49,-$ & $30,-$ & $9,-$ & $11,-$ & $14,-$ & $144,-$ & $29,-$ & - & - & $86.621,-$ \\
\hline Taxable Tax & $4.637,-$ & $10.838,-$ & $9.292,-$ & $359.206,-$ & $753,-$ & $74,-$ & $37,-$ & $10,-$ & $34,-$ & $7,-$ & $144,-$ & $29,-$ & - & - & $86.887,-$ \\
\hline Irregularity Fine & $3,-$ & $18,-$ & $1,-$ & - & - & - & - & - & - & - & - & - & - & - & - \\
\hline Special Irregularity Fine & $528,-$ & $67,-$ & $293,-$ & $148,-$ & $50,-$ & $55,-$ & $191,-$ & $58,-$ & $89,-$ & - & & $29,-$ & - & - & \\
\hline \multirow[t]{2}{*}{ Tax Loss Fine } & $7.213,-$ & $10.863,-$ & $9.481,-$ & $434,-$ & $761,-$ & $74,-$ & $36,-$ & $9,-$ & $55,-$ & $24,-$ & $144,-$ & $29,-$ & - & - & $9,-$ \\
\hline & \multicolumn{5}{|c|}{ Stamp Tax } & \multicolumn{5}{|c|}{ Provisional Tax } & \multicolumn{5}{|c|}{ Other Taxes } \\
\hline Inspected Taxpayers & 64 & 97 & 31 & 44 & 28 & 992 & 2.810 & 603 & 1.066 & 312 & 2.445 & 6.145 & 6.030 & 4.367 & 3.880 \\
\hline Reports & 91 & 124 & 42 & 56 & 36 & 1.582 & 3.409 & 1.635 & 1.966 & 562 & 2.640 & 6.699 & 6.342 & 4.753 & 3.871 \\
\hline Declared Tax & $5.044,-$ & $12.510,-$ & $230.753,-$ & 59.354,- & $264,--$ & $38.672,-$ & $50.834,-$ & $20.531,-$ & $32.711,-$ & $20.069,-$ & $439.285,-$ & $339.966,-$ & $371.735,-$ & $120.152,-$ & $433.085,-$ \\
\hline Tax Base Difference & $24.103,-$ & $48.963,-$ & 42.966,- & $110.599,-$ & $7.911,-$ & $44.551,-$ & $97.142,-$ & $33.095,-$ & $81.930,-$ & 49.155,- & $156.509,-$ & $675.822,-$ & $339.927,-$ & $157.605,-$ & $106.399,-$ \\
\hline Difference/Inspected & $477,85 \%$ & $391,39 \%$ & $18,62 \%$ & $186,34 \%$ & $2996,59 \%$ & $115,20 \%$ & $191,10 \%$ & $161,20 \%$ & $250,47 \%$ & $244,93 \%$ & $35,63 \%$ & $198,79 \%$ & $91,44 \%$ & $131,17 \%$ & $24,57 \%$ \\
\hline Non-declared & $82,69 \%$ & $79,65 \%$ & $15,70 \%$ & $65,08 \%$ & $96,77 \%$ & $53,53 \%$ & $65,65 \%$ & $61,71 \%$ & $71,47 \%$ & $71,01 \%$ & $26,27 \%$ & $66,53 \%$ & $47,77 \%$ & $56,74 \%$ & $19,72 \%$ \\
\hline Tax Difference & $1.379,-$ & $564,-$ & $1.791,-$ & $1.871,-$ & $448,-$ & $4.034,-$ & $3.642,-$ & $3.883,-$ & $8.874,-$ & $7.042,-$ & $3.003,-$ & $10.663,-$ & $138.574,-$ & $4.861,-$ & $5.389,-$ \\
\hline Taxable Tax & $1.519,-$ & $422,-$ & $1.794,-$ & $1.888,-$ & $687,-$ & $4.185,-$ & $3.273,-$ & $3.591,-$ & $9.069,-$ & $5.715,-$ & $4.146,-$ & $10.842,-$ & $8.505,-$ & $4.966,-$ & $5.451,-$ \\
\hline Irregularity Fine & $2,-$ & & & $1,-$ & - & $8,-$ & $15,-$ & $112,-$ & $4,-$ & $2,-$ & $89,-$ & $453,-$ & $50,-$ & $37,-$ & $5,-$ \\
\hline Special Irregularity Fine & $16,-$ & $417,-$ & $158,-$ & $5,-$ & $5,-$ & $2.896,-$ & $1.911,-$ & $2.714,-$ & $1.252,-$ & $476,-$ & $4.182,-$ & $10.333,-$ & $7.077,-$ & $5.715,-$ & $6.117,-$ \\
\hline Tax Loss Fine & $1.557,-$ & $450,-$ & $1.910,-$ & $2.715,-$ & $804,-$ & $8.922,-$ & $4.403,-$ & $5.265,-$ & $11.221,-$ & $9.577,-$ & $2.947,-$ & $8.075,-$ & $2.881,-$ & $3.224,-$ & $5.391,-$ \\
\hline
\end{tabular}

Resource: It was created by using the annual reports published by GiB in 2013, 2014, 2015a, 2016 and $2017 \mathrm{a}$. 


\section{LITERATURE REVIEW}

The studies related to the effectiveness of information economy in prevention of informal economy in Turkey, the role of electronic applications enforced by the GiB and the legal dimension of the applications and the role of accounting profession in preventing tax loss and evasion are presented in Table 5 in summary and chronologically.

Table 5: Literature on Investigation of E-Information, Informality and Tax Loss-Evasion Relationship in Turkey

\begin{tabular}{|c|c|c|}
\hline $\begin{array}{l}\text { Ay, H. M. } \\
(2006)\end{array}$ & $\begin{array}{l}\text { The Efficiency of } \\
\text { Information Economy in } \\
\text { Avoiding The Unregistered } \\
\text { Economy and Role of } \\
\text { Revenue Administration in } \\
\text { Turkey }\end{array}$ & $\begin{array}{l}\text { In the study, informality and its reasons are conceptually } \\
\text { mentioned and its effects on economy are evaluated. In } \\
\text { addition, taking into account the role of information } \\
\text { economy and e-government applications in preventing the } \\
\text { informality; the measures that can be taken in accelerating } \\
\text { e-taxpayer applications have been mentioned. }\end{array}$ \\
\hline $\begin{array}{c}\text { Turan, A. H. and Özgen, } \\
\text { F. B. } \\
\text { (2009) }\end{array}$ & $\begin{array}{l}\text { Adoption of E-Declaration } \\
\text { System in Turkey: An } \\
\text { Empirical Assessment with } \\
\text { the Extended Technology } \\
\text { Acceptance }\end{array}$ & $\begin{array}{l}\text { In the study, the adoption of the e-declaration application by } \\
\text { accounting professionals and the reasons underlying it have } \\
\text { been researched. As a result, it has been determined that } \\
\text { intentions are positive in terms of compatibility, } \\
\text { convenience, perceived ease of usage and usefulness. } \\
\text { However, their intentions can not be predicted in terms of } \\
\text { the impact of relatives and self-reliance. }\end{array}$ \\
\hline $\begin{array}{l}\text { Oral, G. B. } \\
\text { (2011) }\end{array}$ & $\begin{array}{c}\text { Fighting Against Strategies } \\
\text { of Fiscal Corruption: Turkish } \\
\text { Tax System }\end{array}$ & $\begin{array}{l}\text { In the study, anti-corruption strategies in the Turkish tax } \\
\text { system were put forward and it was emphasized that it } \\
\text { would be effective to carry out systematic institutional } \\
\text { reforms, to create ethical codes, to make improvements and } \\
\text { to ensure voluntary tax compliance. On the other hand, } \\
\text { situations such as the usage of information technology, } \\
\text { determination of performance standards and the } \\
\text { establishment of internal control units are also discussed. }\end{array}$ \\
\hline $\begin{array}{l}\text { Öz, E. and Bozdoğan, D. } \\
\text { (2012) }\end{array}$ & $\begin{array}{l}\text { E-Financial Applications in } \\
\text { Turkish Tax System }\end{array}$ & $\begin{array}{l}\text { In the study, e-financial applications were examined within } \\
\text { the framework of legislation and deficiencies in } \\
\text { implementation were identified and solution proposals were } \\
\text { presented. On the other hand, it is stated that with the } \\
\text { usage of information technology, both the efficiency of tax } \\
\text { auditing and the positive social externalities will be } \\
\text { increased. }\end{array}$ \\
\hline $\begin{array}{l}\text { Acar, V. and Öksüz, Ö. } \\
\text { (2013) }\end{array}$ & $\begin{array}{l}\text { Financial Information } \\
\text { Sharing Electronically and } \\
\text { Electronic Ledger } \\
\text { Applications }\end{array}$ & $\begin{array}{l}\text { In the study, e-ledger application was handled on the basis } \\
\text { of the Extensible Business Reporting Language. On the other } \\
\text { hand, the efficiency and effectiveness of information } \\
\text { technology usage has been examined in terms of tax } \\
\text { applications. As a result of the study, it is stated that with } \\
\text { the widespread of e-ledger usage, expenditures can be } \\
\text { controlled and corruption can be prevented. }\end{array}$ \\
\hline $\begin{array}{l}\text { Şençiçek, T.F. } \\
\text { (2013a) }\end{array}$ & $\begin{array}{l}\text { The Effect on The } \\
\text { Accounting Practices of } \\
\text { Development in The } \\
\text { Information Technology: E- } \\
\text { Accounting }\end{array}$ & $\begin{array}{l}\text { In the study, electronic applications are considered in terms } \\
\text { of accounting and evaluated in terms of integrated systems. } \\
\text { As a result of the study, it has been revealed that electronic } \\
\text { applications provide workforce, time saving and increased } \\
\text { competitive power. }\end{array}$ \\
\hline $\begin{array}{c}\text { Şençiçek, T.F. } \\
\text { (2013b) }\end{array}$ & $\begin{array}{c}\text { Holistic Approach to } \\
\text { Information Technology } \\
\text { Aided Accounting Practices }\end{array}$ & $\begin{array}{l}\text { In the study, the relationship between electronic accounting } \\
\text { applications and Extensible Business Reporting Language has } \\
\text { been examined. As a result of the study, it is stated that the } \\
\text { quality and efficiency of accounting applications will increase } \\
\text { with the usage of robust information technology. }\end{array}$ \\
\hline
\end{tabular}




\begin{tabular}{|c|c|c|}
\hline $\begin{array}{l}\text { Şakar, A.Y. and Ayrancl, } \\
\text { E. } \\
\text { (2014) }\end{array}$ & $\begin{array}{l}\text { Attitudes towards E- } \\
\text { Bookkeeping in Turkey: } \\
\text { Initial Research }\end{array}$ & $\begin{array}{l}\text { In the study, the attitudes of professional accountants to e- } \\
\text { bookkeeping applications are discussed. As a result of the } \\
\text { study, It has been found out that the attitudes of the } \\
\text { members of the profession depend on five factors and that } \\
\text { only the magnitude of the business causes attitude change. }\end{array}$ \\
\hline $\begin{array}{l}\text { Aslan, M. } \\
\text { (2014) }\end{array}$ & $\begin{array}{l}\text { Evaluation of the Legal } \\
\text { Validity of The Electronic } \\
\text { Documents in Taxation }\end{array}$ & $\begin{array}{l}\text { In the study, the electronic applications of the GiB were } \\
\text { examined on the legal level and suggestions were made to } \\
\text { eliminate potential legal problems. }\end{array}$ \\
\hline $\begin{array}{l}\text { Güney, S. and Özyiğit H. } \\
\qquad(2015)\end{array}$ & $\begin{array}{l}\text { The Use of Accounting Data } \\
\text { in Management and The } \\
\text { Effect of Electronic } \\
\text { Accounting Data on } \\
\text { Management Decision }\end{array}$ & $\begin{array}{l}\text { In the study, electronic accounting data which gain a new } \\
\text { function with advanced technology and to what extent these } \\
\text { data affect management decisions. As a result of the study, } \\
\text { it was emphasized that it affected decisions to be taken in } \\
\text { terms of management accounting. }\end{array}$ \\
\hline $\begin{array}{l}\text { Beşel, F. and Çokgezer, C. } \\
\qquad(2015)\end{array}$ & $\begin{array}{l}\text { E-Technologies and Their } \\
\text { Efficiency in Public Finance }\end{array}$ & $\begin{array}{l}\text { In the study, the usefulness and shortcomings of the } \\
\text { information technologies used in the field of public finance } \\
\text { are addressed and evaluations are made within the } \\
\text { framework of the reports published by GiB. The applications } \\
\text { are classified in } 3 \text { groups and the deficiencies are indicated. } \\
\text { As a result of the study, it is stated that the systems that are } \\
\text { used in the field of tax need to be developed. }\end{array}$ \\
\hline $\begin{array}{l}\text { Gökçen, G. and Özdemir, } \\
\text { M. } \\
\text { (2016) }\end{array}$ & $\begin{array}{l}\text { E-Book and E-Invoicing } \\
\text { Practices from Accounting } \\
\text { Practices in Turkey }\end{array}$ & $\begin{array}{l}\text { In the study, e-invoice and e-ledger have been examined and } \\
\text { it has been mentioned that applications will bring } \\
\text { advantages such as easy access, archiving and cost } \\
\text { advantages as well as disadvantages such as infrastructure } \\
\text { inadequacy and insecurity in terms of businesses. It is also } \\
\text { stated that electronic applications increase the auditing } \\
\text { efficiency of the government and help preventing tax loss } \\
\text { and evasion. }\end{array}$ \\
\hline $\begin{array}{l}\text { Merter, M. E. } \\
\text { (2016) }\end{array}$ & $\begin{array}{l}\text { The Analysis of The Impact } \\
\text { of E-Declaration of Taxes on } \\
\text { The Effectiveness of Tax } \\
\text { Auditings }\end{array}$ & $\begin{array}{l}\text { In the study, the relationship between e-declaration and tax } \\
\text { auditing was examined and the effectiveness of electronic } \\
\text { applications was searched. As a result of the study, it has } \\
\text { been revealed that electronic notification will increase the } \\
\text { quality of tax auditing and prevent possible tax losses. }\end{array}$ \\
\hline $\begin{array}{l}\text { Azak, S. T. and Bizimyer, } \\
\text { M. } \\
\text { (2016) }\end{array}$ & $\begin{array}{l}\text { The Evaluation of E-Invoice } \\
\text { in Terms of Tax Laws }\end{array}$ & $\begin{array}{l}\text { In the study, e-invoice application was handled within the } \\
\text { framework of legal legislation. The usage of e-information } \\
\text { and its benefits to businesses and states are mentioned. As a } \\
\text { result of the study, it was emphasized that the usage of e- } \\
\text { invoice would facilitate cost-benefit analysis for taxpayers, } \\
\text { reconciliation and collection. }\end{array}$ \\
\hline $\begin{array}{l}\text { Arslan, M. and Biniş, M. } \\
\qquad \text { (2016) }\end{array}$ & $\begin{array}{l}\text { Tax Notification in Turkish } \\
\text { Tax System and Electronic } \\
\text { Notification }\end{array}$ & $\begin{array}{l}\text { In the study, regulations regarding the implementation of } \\
\text { the notification process in electronic environment, which is } \\
\text { important in tax process, have been examined. As a result of } \\
\text { the study, it is mentioned that e-notification which } \\
\text { overcomes the probable problems in declaration, } \\
\text { contributes to the increase of quality of communication } \\
\text { between the Revenue Administration and the taxpayers. }\end{array}$ \\
\hline
\end{tabular}

As seen in the table, considering the quantitative and qualitative research methodology, it can be said that researches about the e-information usage in accounting applications are very few. On the other hand, it has been determined that the 
usage of e-information is not considered as a whole in terms of accounting applications. In this respect, the situation of einformation usage in Turkey has been evaluated in terms of accounting applications.

On the other hand, considering the international literature about the usage of e-information in accounting, it has been observed that this field has been studied in practical dimension in recent years. Some of these studies can be exemplified as follows. The study of e-accounting practices by Venegas et al. (2016) emphasized that tax losses were high in Mexico due to high tax rates. As a result of the study, it has been revealed that the financial transactions carried out together with the eaccounting which has been put into practice monthly publication on the website will increase the efficiency of auditing. On the other hand, Lee (2016), in his study of e-invoice's effects on tax harmonization, found that e-invoice application increased transaction transparency, facilitating transactions for taxpayer and effective in preventing tax evasion. In another study, Ali (2016) mentioned that it is crucial to use e-invoice in terms of the cost-benefit analysis, referring to the quick payment, minimazing the cost of stationery and reduction of manual transactions. In another study, Palupi and Darwanto (2017) investigated the effect of the e-invoice application on transaction costs. As a result of the study, they found that transaction costs increases significantly in the adaptation period rather than decreasing, but the desired results can be achieved at the end of the one-year period.

\section{THE USAGE OF E-INFORMATION IN TERMS OF ACCOUNTING APPLICATIONS IN TURKEY AND ITS ROLE IN STRUGGLE WITH INFORMALITY}

Integrity, accuracy, timeliness and impartiality are important in terms of individuals and businesses as well as public institutions and organizations in the process of obtaining, recording, transferring and feedback of financial information in a proper and appropriate manner. In this context, besides providing speed and savings in processes, electronic applications are needed to increase productivity and efficiency in activities. As a matter of fact, some studies are being carried out by GiB under the framework of e-government applications in order to reduce informality, to collect public taxes and other incomes fully, timely and by using modern methods, to provide continuous control and to use e-information effectively. Applications such as e-declaration, e-invoice, e-ledger, e-poll and e-notification that are put into effect within the scope of these studies are also directly related to the accounting profession which serves as a bridge between taxpayers and tax offices in taxation based on declaration basis.

It can be said that electronic applications that are put into effect in terms of accounting practices are effective in preventing tax loss and evasion. However, tax revenues are risky for the registered economy because they are collected on the basis of declaration. It has been demonstrated that the usage of information technologies and e-information may be beneficial in preventing such risks (GiB, 2017b: 64-67). On the other hand, with the efficient usage of e-information, cost minimization for public administrations and businesses will also be achieved. Furthermore, thanks to electronic applications, effectiveness of tax and internal auditing will also increase. Regarding the aforementioned electronic applications, the number of users over the years registered by GiB is shown in Table 6.

Table 6: The Numerical Information About The Usage of Electronic Applications

\begin{tabular}{|c|c|c|c|c|c|}
\hline Number of Users & 2012 & 2013 & 2014 & 2015 & 2016 \\
\hline E-Declaration & $55000000^{*}$ & $67000000 *$ & 75160223 & $82000000 *$ & $90000000 *$ \\
\hline E-Invoice & 3182 & 16270 & 19375 & 46800 & 61013 \\
\hline E-Ledger & 28 & 47 & 18500 & 45321 & 59451 \\
\hline E-Archive & 6 & 6 & 17 & 1915 & 6161 \\
\hline E-Ticket & - & - & 1 & 1 & 18 \\
\hline E-Poll & - & - & - & 3500 & 4000 \\
\hline E-Notification & - & - & - & 49706 & 3719221 \\
\hline
\end{tabular}

* The number of taxpayers who filled in e-declaration has been expressed approximately.

Resource: GiB, 2017a: 107-113

As seen in the table, e-declaration that put into effect in 2004, is filled electronically by approximately 90000000 taxpayers as of 2016. This situation provides in addition to saving time and workforce, also allows to reduce possible errors and stationary expenses in terms of accounting professional who serves as a bridge between tax offices and taxpayers. On the other hand, transactions such as signing, transferring, preservation and submission of invoices are made in electronic environment by e-invoices that put into effect in 2010. Thus, the costs incurred by the classic paper billing concept are avoided and the invoice transferring is carried out mutually online. As of 2010, 114, as of 2016, 61013 taxpayers are registered with the e-invoice registration system. Information about e-invoice and e-archieve applications over the years is shown in Table 7. 
Table 7: The Numerical Information About E-Invoice and E-Archive Usage

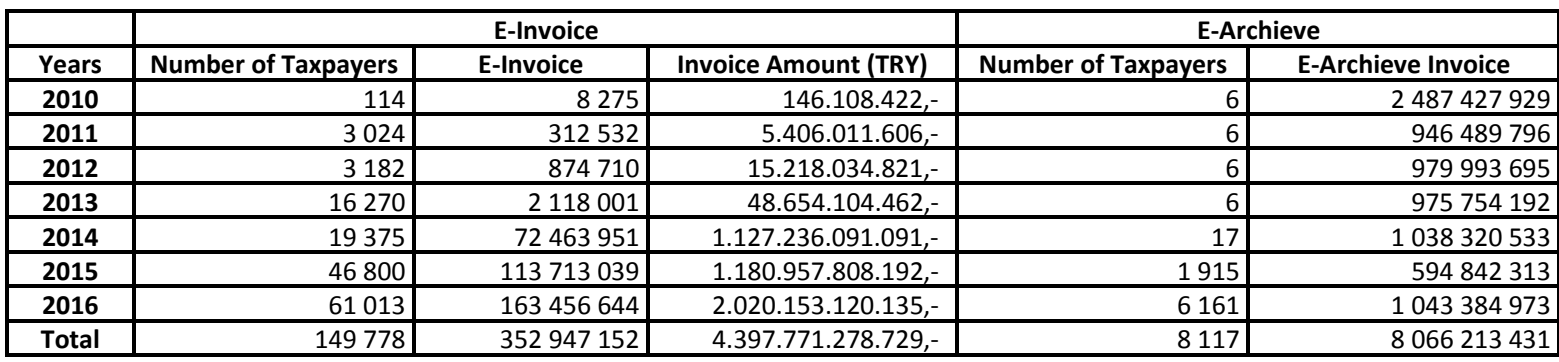

Resource: GiB, 2017a: 107-108

As seen in the table, it can be stated that number of issued e-invoices and depending on its increment, the share of the recorded transactions in economy has increased over the years. Thanks to this application, significant distances have been achieved in preventing tax loss and evasion. On the other hand, e-archive application provides data storage about e-invoice for many years. Thus, the goal of increasing the effectiveness of auditing process can be realized both in terms of businesses and public authority. The number of invoices under e-archive application has been increasing over the years. By means of applications such as e-archieve and e-poll, it is aimed to expand the GiB database and to be able to access the information quickly, to analyze the obtained data easily and to increase the effectiveness of auditing. In this context, e-poll, which was implemented by 3500 mobile phones in September 2015, has been increased to 4000 in 2016 . Thus, along with the mobility provided by the electronic environment, immediate intervention is realized in inappropriate situations. As of 2016, the number of inspection for unregistered activities is 5912 (GIB, 2017a: 110).

Financial transactions can be recorded into daybook and ledger which are held on behalf of taxpayers, electronically by accountants thanks to the e-ledger system. The number of taxpayers who use e-ledger application is 28 in 2012 and 59451 as of 2016. This practice provides advantage of cost reduction for professionals, tax inspection and auditing which can be made in electronic environment with remote access. In addition to these, the number of e-tickets and e-notifications that have been implemented, has also increased over the years. With the e-notification, a total of 3719221 notifications and payment order were delivered to the interested parties in 2016, totally of 40.642.316,- TRY saving have been achieved (GiB, 2017a: 113). Effective usage of such electronic applications contributes to increasing the quality of communication between tax administrations and taxpayers and minimizing their costs. As a matter of fact, the situation regarding the tax collection for the GiB and the expenditures made for the realization of this collection by years are shown in Table 8.

Table 8: The Comparison of General Budget Tax Revenues Collection and Revenue Administration Expenditures

\begin{tabular}{|l|r|r|r|}
\hline Years & Tax Revenue (Thousand TRY) & GiB Expenditures (Thousand TRY) & Collection Expenditures per 100,- TRY Tax \\
\hline $\mathbf{2 0 0 6}$ & $151.271 .701,-$ & $1.152 .887,-$ & 0,76 \\
\hline $\mathbf{2 0 0 7}$ & $171.098 .466,-$ & $1.274 .631,-$ & \\
\hline $\mathbf{2 0 0 8}$ & $189.980 .827,-$ & $1.420 .975,-$ & 0,74 \\
\hline $\mathbf{2 0 0 9}$ & $196.313 .308,-$ & $1.607 .396,-$ & 0,75 \\
\hline $\mathbf{2 0 1 0}$ & $235.714 .637,-$ & $1.637 .613,-$ & 0,82 \\
\hline $\mathbf{2 0 1 1}$ & $284.490 .017,-$ & $1.935 .998,-$ & 0,69 \\
\hline $\mathbf{2 0 1 2}$ & $317.218 .619,-$ & $2.179 .670,-$ & 0,68 \\
\hline $\mathbf{2 0 1 3}$ & $367.517 .727,-$ & $2.095 .646,-$ & 0,69 \\
\hline $\mathbf{2 0 1 4}$ & $401.683 .856,-$ & $2.313 .804,-$ & \\
\hline $\mathbf{2 0 1 5}$ & $465.229 .389,-$ & $2.471 .875,-$ & \\
\hline $\mathbf{2 0 1 6}$ & $529.263 .765,-$ & $2.875 .482,-$ & \\
\hline
\end{tabular}

Resource: GiB, 2017a: 180

As seen in the table, while the collections made regarding the general budget tax revenues have shown an increase over the years, the expenditures are in a right proportional course. On the other hand, the expenditures made to collect per 100,- TRY tax are decreasing over the years. As a matter of fact, the expenditure of 0,76 TRY, which GiB made to collect taxes for every 100, -TRY in 2006, decreased to 0,54 TRY as of 2016. Expenditures are expected to decline further in the long run, coupled with increased usage of information technology and e-information. As a matter of fact, the fact that there is a trend in direction of decreasing expenditures over the years, has strengthened this expectation. It can be said that the positive situations in terms of economy are realized by putting e-financial applications into effect. In this context, electronic applications and comparative information about tax loss and evasion are summarized in Table 9. 
Table 9: The Comparison of E-Information Usage with Tax Loss and Evasion

\begin{tabular}{|c|c|c|c|c|c|c|c|c|c|}
\hline \multirow[b]{2}{*}{ Years } & \multirow{2}{*}{$\begin{array}{c}\text { GDP } \\
\text { (Thousand TRY) }\end{array}$} & \multicolumn{4}{|c|}{ Tax (Thousand TRY) } & \multicolumn{4}{|c|}{ Electronic Applications } \\
\hline & & Accruals & Collection & $\begin{array}{c}\text { Tax } \\
\text { Loss } \\
\end{array}$ & $\begin{array}{c}\text { As a Result of Non- } \\
\text { Declared }\end{array}$ & E-Declaration & E-Invoice & E-Ledger & E-Notification \\
\hline 2012 & $1.569 .672,-$ & $366.964,-$ & $317.219,-$ & $\% 13,6$ & $\% 32,39$ & 55000000 & 3182 & 28 & - \\
\hline 2013 & $1.809 .713,-$ & $423.439,-$ & $367.518,-$ & $\% 13,2$ & $\% 57,87$ & 67000000 & 16270 & 47 & - \\
\hline 2014 & $2.044 .466,-$ & $471.416,-$ & $401.684,-$ & $\% 14,8$ & $\% 31,23$ & 75160223 & 19375 & 18500 & - \\
\hline 2015 & $2.337 .530,-$ & $549.260,-$ & $465.229,-$ & $\% 15,3$ & $\% 40,85$ & 82000000 & 46800 & 45321 & 49706 \\
\hline 2016* & - & $651.822,-$ & $529.264,-$ & $\% 18,8$ & $\% 33,51$ & 90000000 & 61013 & 59451 & 3719221 \\
\hline
\end{tabular}

* 4th quarter data on 2016 GDP has not been published yet.

As seen in the table, accruals and collection have increased over the years. However, the collection of the accrued tax has not been fully realized. This situation indicates tax loss and the existence of the informality in relation to it. However, when the tax loss is examined in terms of accrual-collection over the years, it is decreasing compared to previous years. As a matter of fact, this situation supports the non-declared ratios revealed as a result of the tax inspections. On the other hand, the increase in the applications such as e-declaration, e-invoice, e-ledger which are applied electronically, accelerates the transition to the registered economy. In this context, the increment in tax accruals and collections is giving rise to the impression that the declared tax base is close to reflecting reality. Moreover, trend of declining informality/GDP ratio in recent years is an important indicator of the effectiveness of e-financial applications.

\section{CONCLUSION}

It can be expressed that electronic instruments such as e-declaration, e-invoice, e-ledger and e-notification that are used in accounting applications, when evaluated as a whole, directly affect the activities of professional accountants by saving time, reducing transaction costs and bringing important results that are effective in processes. Similarly, it can be observed that these applications in terms of public administration provide efficiency in activities, quality in auditing, fast mobility in operations and remote access; the decrease in the tax collection expenses, the increase in the collection/accrual rate, and thus the improvement can be partially attributed to decrease of tax loss and evasion which is both cause and consequence of informality.

The importance of developing and disseminating e-information instruments that enable coordination between institutions in the struggle with informality in Turkey can not be denied. In this framework, it can easily be expressed that the accounting profession, which serves as a bridge between the taxpayers and the tax offices, will provide important contributions through its activities to this coordination.

On the other hand, when struggling with informality, it would be unrealistic to expect e-information instruments alone to be enough to solve all possible problems. In order to be fully successful, in addition to using e-information instruments in the most effective way, revisioning of other principles of taxation (such as fairness, impartiality, transparency and accountability of taxation, observing benefit/cost balance in public expenditures, etc.) are the factors that will contribute to the prevention of informality.

Finally, in the case of obtaining detailed statistical data and information about the usage of e-information, it can be said that more comprehensive assessment of this topic can be made and thus it can contribute to academic literature.

\section{REFERENCES}

Acar, V. and Öksüz, Ö. (2013), "Finansal Bilgilerin Elektronik Ortamda Paylaşımı ve E-Defter Uygulamaları", Akademik Araştırmalar ve Çalışmalar Dergisi, 5(8), 62-89.

Ali, Nazish (2016), “Adapting E-Invoicing: Benefits, Challenges and Future Strategies to Overcome Challenges - A Comparative Case Study of Finnish Companies", Vaasan Ammattikorkeakoulu University of Applied Sciences, Finland.

Arslan, M. and Biniş, M. (2016), "Türk Vergi Sisteminde Tebligat ve Elektronik Tebligat”, Yönetim ve Ekonomi Araştırmaları Dergisi, 14(1), 300-317.

Aslan, M. (2014), "Vergilendirmede Elektronik Belgelerin Hukuki Geçerliliklerinin Değerlendirilmesi", Siyaset, Ekonomi ve Yönetim Araştırmaları Dergisi, 2(3), 21-58.

Ay, H. M. (2006), "Türkiye'de Kayıtdışı Ekonomiyi Önlemede Bilgi Ekonomisinin Etkinliği ve Gelir İdaresinin Rolü”, Selçuk Üniversitesi Karaman i.i.i.B.F. Dergisi, 11(9), 57-81.

Azak, S. T. and Bizimyer, M. (2016), “Elektronik Faturanın Vergi Kanunları Açısından Değerlendirilmesi”, Mali Çözüm Dergisi, Mayıs-Haziran, 154-167. 
Bağırzade, E. R. (2015), “Kayıtdışı Sektörün Ekonomideki Rolü Tartışmaları Üzerine: Bir Literatür Taraması”, Uluslararası İktisadi ve İdari Incelemeler Dergisi, 7(14), 39-54.

Beşel, F. and Çokgezer, C. (2015), "Maliye Alanında E-Teknolojiler ve Etkinliği”, Uluslararası Ekonomik Araştırmalar Dergisi, 1(1), 13-23.

Daştan, A. (2011), “Muhasebe Meslek Mensuplarının Vergi Kayıp ve Kaçaklarının Önlenmesindeki Rolü: Doğu Karadeniz Bölgesine Yönelik Bir Araştırma", Atatürk Iktisadi ve İdari Bilimler Dergisi, 25(2), 181-206.

Gelir Idaresi Başkanlı̆̆ı, (2013), "2012 Yılı Faaliyet Raporu”, Yayın Nr.:167, Ankara.

Gelir İdaresi Başkanlı̆̆ı, (2014), "2013 Yııı Faaliyet Raporu”, Yayın Nr.:187, Ankara.

Gelir İdaresi Başkanlığı, (2015a), "2014 Yılı Faaliyet Raporu”, Yayın Nr.:199, Ankara.

Gelir İdaresi Başkanlığı, (2015b), “Kayıtdışı Ekonominin Azaltılması Programı Eylem Planı”, Onuncu Kalkınma Planı (2014-2018), Ankara.

Gelir İdaresi Başkanlı̆̆ı, (2016), "2015 Yılı Faaliyet Raporu”, Yayın Nr.:216, Ankara.

Gelir İdaresi Başkanlığı, (2017a), "2016 Yılı Faaliyet Raporu”, Yayın Nr.:247, Ankara.

Gelir İdaresi Başkanlığı, (2017b), "2017 Yılı Performans Raporu”, Yayın Nr.:228, Ankara.

Gökçen, G. and Özdemir, M. (2016), “Türkiye’de Muhasebe Uygulamalarından E-Defter ve E-Fatura Uygulaması”, Marmara Üniversitesi Öneri Dergisi, 12(46), 137-154.

Güney, S. and Özyiğit, H. (2015), “Muhasebedeki Verilerin Yönetimde Kullanılması ve Elektronik Muhasebe Verilerinin Yönetim Kararlarına Etkisi”, Elektronik Sosyal Bilimler Dergisi, 14(53), 279-297.

http://www.gib.gov.tr/sites/default/files/fileadmin/user_upload/VI/GBG/Tablo_2.xls.htm Erişim Tarihi: 27.03.2017

http://www.gib.gov.tr/sites/default/files/fileadmin/user_upload/VI/GBG/Tablo_18.xls.htm Erişim tarihi: 27.03.2017

http://www.gib.gov.tr/sites/default/files/fileadmin/user_upload/VI/GBG/Tablo_55.xls.htm Erişim tarihi: 27.03.2017

http://www.gib.gov.tr/sites/default/files/fileadmin/user_upload/VI/GBG/Tablo_56.xls.htm Erişim tarihi: 27.03.2017

Lee, H. C. (2016), “Can Electronic Tax Invoicing Improve Tax Compliance? A Case Study of the Republic of Korea's Electronic Tax Invoicing for Value-Added Tax", World Bank Group, Policy Research Working Paper, 7592.

Merter, M. E. (2016), "Ülkemizde E-Beyanname Uygulamasının Vergi Denetiminin Etkinliği Üzerindeki Etkisi”, CBÜ Sosyal Bilimler Dergisi, $14(2), 52-73$.

Oral, G. B. (2011), “Mali Yolsuzlukla Mücadele Stratejileri: Türk Vergi Sistemi”, Süleyman Demirel Üniversitesi İktisadi ve İdari Bilimler Fakültesi Dergisi, 16(3), 403-431.

Öz, E. and Bozdoğan, D. (2012), "Türk Vergi Sisteminde E-Maliye Uygulamaları”, Süleyman Demirel Üniversitesi ỉktisadi ve İdari Bilimler Fakültesi Dergisi, 17(2), 67-92.

Palupi, C. and Darwanto (2017), "Transaction Cost on The Implementation of E-Invoices in Micro and Small Enterprises", Jurnal IImu Ekonomi, 6(1), 139-158.

Rakıcı, C. (2011), “Vergi Denetiminin Yeni Yapısı ve Denetimin Kayıtdışılığı Önleme Fonksiyonu”, ZKÜ Sosyal Bilimler Dergisi, 7(14), 345-361.

Savaşan, F. and Odabaş, H. (2005), "Türkiye'de Vergi Kayıp ve Kaçaklarının Nedenleri Üzerine Ampirik Bir Çalışma", Sosyal Ekonomik Araştırmalar Dergisi, 10, 1-28.

Schneider, F. (2005), “Dünyanın 110 Ülkesindeki Kayıtdışı Ekonominin Büyüklüğü ve Ölçümü”, Maliye Bakanlığı APK Kurulu Başkanlığı, Rapor No:11, Ankara.

Schneider, F. and Buehn, A. (2016), "Estimating The Size of The Shadow Economy: Methods, Problems and Open Qestions", IZA Discussion Paper, No.9820, Germany.

Schneider, F. and Williams, C. C. (2013), "The Shadow Economy", The Institute of Economic Affairs, London.

Şakar, A.Y. and Ayrancı, E. (2014), "Attitudes towards E-Bookkeeping in Turkey: Initial Research", International Journal of Academic Research in Accounting, Finance and Management Sciences, 4(1), 52-66.

Şençiçek, T. F. (2013a), "Bilişim Teknolojilerinde Gelişmelerin Muhasebe Uygulamalarına Etkisi: E-Muhasebe”, Sosyal ve Beşeri Bilimler Dergisi, 5(2), 89-102.

Şençiçek, T. F. (2013b), “Bilgi Teknolojileri Destekli Elektronik Muhasebe Uygulamalarına Bütüncül Bir Yaklaşım”, Organizasyon ve Yönetim Bilimleri Dergisi, 5(2), 79-90.

Turan, A. H. and Özgen, F. B. (2009), “Türkiye'de E-Beyanname Sisteminin Benimsenmesi: Geliştirilmiş Teknoloji Kabul Modeli ile Ampirik Bir Çalışma", Doğuş Üniversitesi Dergisi, 10(1), 134-147.

Türker, M. (2004), “Vergi Kayıplarının Önlenmesinde Muhasebe Meslek Mensuplarının Vergi Beyannamelerini İmzalaması ve Maliye Bakanlığına Bir Öneri”, TÜRMOB Yayınlar, 249.

Venegas, R.R., Fernandez, E.A. and Maldonado, G.O, (2016), "The Diffusion of An Authoritarian Innovation In Implementation of The EAccounting in Mexico", European Journal of Business and Social Sciences, 5(7), 51-65. 